\title{
The 55-kD Tumor Necrosis Factor Receptor and CD95 Independently Signal Murine Hepatocyte Apoptosis and Subsequent Liver Failure
}

\author{
Marcel Leist,* Florian Gantner,* Gerald Künstle,* \\ Ines Bohlinger, ${ }^{*}$ Gisa Tiegs, ${ }^{*}$ Horst Bluethmann, ${ }^{\dagger}$ \\ and Albrecht Wendel* \\ *Faculty of Biology, University of Konstanz, Konstanz, Germany \\ ${ }^{\dagger}$ F. Hoffmann-La Roche AG, Basel, Switzerland
}

\begin{abstract}
Background: Activation of either the $55-\mathrm{kD}$ tumor necrosis factor receptor (TNF-R1) or CD95 (Fas/Apo-1) causes apoptosis of cells and liver failure in mice, and has been associated with human liver disorders. The aim of this study was first to clarify the association between CD95 activation, hepatocyte apoptosis, and fulminant liver failure. Next, we investigated whether TNF-Rl and CD95 operate independently of each other in the induction of hepatocyte apoptosis.

Materials and Methods: Using both mice and primary liver cell cultures deficient in either TNF-R 1 or functional CD95, the induction of apoptosis and hepatocyte death following activation of TNF-R1 or CD95 were studied in vitro and in various in vivo models of acute liver failure.
\end{abstract}

Results: In vivo or in vitro stimulation of CD95 caused apoptosis of wild-type $(w t)$ murine hepatocytes which had not been sensitized by blocking transcription. Time course studies showed that DNA fragmentation and chromatin condensation preceded, respectively, membrane lysis in vitro and necrosis in vivo. Similar results were obtained after CD95 activation in hepatocytes or livers lacking TNF-R1. Conversely, hepatocytotoxicity due to endogenous or exogenous TNF was not affected in animals or liver cell cultures lacking the expression of functional CD95.

Conclusions: TNF-R1 and CD95 are independent and differentially regulated triggers of murine apoptotic liver failure.

\section{INTRODUCTION}

The cytokine receptors TNF-R1 (CD12la) and CD95 (Fas[1], Apo-1 [2]) belong to the nerve growth factor/tumor necrosis factor receptor (TNF-R) familiy (3). All members of this family share common structural features in their extracellular regions, such as multiple cysteine-rich domains. Their cytoplasmic tails do not display significant homology except for an 80-amino acid motif expressed on TNF-R1, CD95, and some less well characterized proteins which interact with these two surface receptors (4).

Since activation of both TNF-R1 and CD95 by natural ligands and agonistic antibodies, respectively, causes apoptosis (5-10) by signaling through this 80 -amino acid motif, it has been

Address correspondence and reprint requests to: Albrecht Wendel, Faculty of Biology, University of Konstanz, P.O. Box 5560 M668, D-78434 Konstanz, Germany. termed the "death domain" (11-14). Indeed, it has recently been shown that its overexpression is sufficient to mediate apoptotic cell death in cultured cell lines (15).

In addition to the homology between TNF-R 1 and CD95 (16), a highly conserved functional homology seems to exists between their respective ligands, TNF and CD95L (FasL). Both cytokines are expressed in a membrane bound form that is biologically active $(10,17,18)$, form homotrimers in solution $(19,20)$, and can trigger apoptosis in a large variety of target cells including hepatocytes $(21,22)$. A possible interaction between the signal transduction pathways that mediate apoptosis following TNF-R1 or CD95 activation has been repeatedly discussed (23-28). Several recent in vitro investigations, however, suggested that these two related surface receptors cause cytotoxicity independently of each 
other with respect to activation kinetics (29), signal transduction pathways $(30,31)$, and susceptibility to pharmacological intervention (32).

The liver is one of the organs most affected by septic injury due to systemic inflammatory response syndrome (SIRS). It is generally agreed that during the initial stages of SIRS, high circulating levels of TNF contribute to circulatory failure, organ damage, and lethality. In fact, high TNF release represents the final toxic mechanism common to several murine models of SIRS. Direct injection (33) or induction of endogenous TNF by lipopolysaccharide (34), mitogens (35$37)$, or superantigens $(38-40)$ causes circulatory shock and liver failure. In these models, antibodies directed against TNF completely prevented liver destruction. TNF-triggered liver cell death appears to occur by apoptosis during the early stages of organ damage and is followed by massive secondary necrosis $(21,41,42)$.

An alternate mechanism for triggering apoptosis in murine liver involves the activation of CD95. Injection of an agonistic anti-CD95 antibody (antiCD95) in mice causes lethality and fulminant hemorrhagic liver injury associated with morphological appearance of apoptotic hepatocytes (22). Moreover, it has recently been demonstrated that CD95 expression is increased in livers of patients suffering from viral infection (43) or fulminant hepatitis (44). However, from these in vivo studies it is not clear whether activation of CD95 on the surface of liver parenchymal cells leads directly to apoptosis. Alternatively, it is equally possible that triggering CD95 on nonparenchymal cells initiates the release of a variety of secondary hepatocytotoxic mediators including TNF.

To determine whether CD95-induced hepatocyte apoptosis has a causal role in liver failure, the temporal sequence of events leading to liver cell lysis was determined. In addition, we compared the effect of the transcriptional inhibitor D-galactosamine (GalN) on TNF- or anti-CD95induced hepatocytotoxicity in primary liver cell cultures and in mice. In order to test the existence of a functional relationship or cooperation between the TNF and the CD95 pathways, we used primary murine hepatocyte cultures from mouse strains deficient in TNF-R1 (45) or CD95. These cultures were challenged with either agonistic anti-CD95 $\mathrm{Ab}$ or with TNF. In addition to these in vitro experiments, we used three different models of in vivo hepatic failure in order to compare anti-CD95 or TNF effects in mice deficient for expression of either TNF-R1 or functional CD95.

\section{MATERIALS AND METHODS}

\section{Materials}

Recombinant TNF- $\alpha$ was generously provided by Dr. G. R. Adolf, Bender \& Co. (Vienna, Austria) and rhuIL- $1 \beta$ was from Ciba Geigy (Basel, Switzerland). D-galactosamine was purchased from Roth Chemicals (Karlsruhe, Germany). Salmonella abortus equi endotoxin (LPS) was purchased from Sebak (Aidenbach, Germany). The $n \times 123$ bp molecular weight marker was from Gibco (Eggenstein, Germany). An IgG fraction of ovine anti-murine TNF- $\alpha$ antiserum was prepared as described (8). The agonistic anti-CD95 antibody (22) Jo-2 was from Pharmingen (Hamburg, Germany). Unless further specified, all other reagents were purchased from Sigma (Deisenhofen, Germany).

\section{Animals}

Specific pathogen-free male BALB/c or C57BL/6 mice $(25 \mathrm{~g})$ were from the internal animal breeding house, University of Konstanz. A breeding stock of 55-kD TNF-R (CD121a)-deficient mice (45) and the corresponding wild-type mice (C57BL/6 $\times 129 / \mathrm{Sv}$ ) was provided by Hoffmann LaRoche (Basel, Switzerland). Male MRL/MpJ wild-type as well as lymphoproliferative disorder (lpr) mice ( 10 weeks old; $25 \mathrm{~g}$ ), $\mathrm{C} 3 \mathrm{H} / \mathrm{HeJ}$ (LPSresistant) and $\mathrm{C} 3 \mathrm{H} / \mathrm{HeN}$ (LPS-sensitive) mice were purchased from Harlan (Austerlitz, The Netherlands). Animals were housed at a constant day/night cycle of $12 \mathrm{hr}$ at $22^{\circ} \mathrm{C}$ and $55 \%$ humidity. They were starved overnight for the in vivo experiments and were allowed free access to food and water for the cell preparations. Experiments were generally started at 8 AM. All animals received humane care in adherence to the NIH guidelines as well as to the legal requirements in Germany.

\section{In Vivo Experiments}

The sensitizing agents ActD ( $800 \mu \mathrm{g} / \mathrm{kg}$ ) or GalN $(700 \mathrm{mg} / \mathrm{kg})$ were injected intraperitoneally in $300 \mu \mathrm{l}$ of saline. Concanavalin A $(25 \mathrm{mg} / \mathrm{kg})$ was injected intravenously without sensitizer, and TNF or anti-CD95 were given intravenously in a $300-\mu$ l volume of saline (containing $0.1 \% \mathrm{hu}$ man serum albumin) 1 min after GalN or ActD. Anti-TNF IgG (sufficient to neutralize TNF serum concentrations of $100 \mathrm{ng} / \mathrm{ml}$ ) was given in a volume of $200 \mu \mathrm{l}$ intravenously $15 \mathrm{~min}$ before anti-CD95 and rhulL-1 $\beta$ was given intrave- 
nously $4 \mathrm{hr}$ before the anti-CD95 challenge. Blood was sampled from the tail vein $90 \mathrm{~min}$ after LPS-administration for TNF determinations with the WEHI 164 bioassay according to Espevik and Nissen-Meyer (46). All other samples were obtained after lethal anesthesia of mice by intravenous injection of $150 \mathrm{mg} / \mathrm{kg}$ pentobarbital plus $0.8 \mathrm{mg} / \mathrm{kg}$ heparin. After midline laparatomy and opening of the chest, blood was withdrawn by cardiac puncture and immediately centrifuged for $2 \mathrm{~min}$ at $4^{\circ} \mathrm{C}$ at $13,000 \times g$ to obtain the plasma. Livers were perfused for $10 \mathrm{sec}$ with cold perfusion buffer (PB) $(50 \mathrm{mM}$ phosphate, $120 \mathrm{mM} \mathrm{NaCI}, 10 \mathrm{mM}$ EDTA, pH 7.4), and subsequently excised. A slice of the large anterior lobe was immediately immersed in $4 \%$ buffered formalin solution as a fixation for histological studies. The remaining parts of the liver were disintegrated with three strokes of an Elvehjem type homogenizer. The $20 \%$ homogenate (in PB) was centrifuged at $13,000 \times g$ for $20 \mathrm{~min}$. The supernatant was diluted 270 -fold and used directly in an ELISA designed to detect DNA fragmentation. Alternatively, DNA was precipitated from $450 \mu \mathrm{l}$ of supernatant by addition of $1 \mathrm{ml}$ of ethanol $\left(-20^{\circ} \mathrm{C}\right)$ plus $50 \mu \mathrm{l}$ of sodium chloride $(5 \mathrm{M})$ or sodium acetate $(3 \mathrm{M})$ and stored at $-20^{\circ} \mathrm{C}$ for further analysis on agarose gels.

\section{Hepatocyte Cultures}

Hepatocytes were isolated by the two-step collagenase perfusion method of Seglen (47) with a viability exceeding $80 \%$ according to the trypan blue exclusion method. Cells were plated in $200 \mu \mathrm{l}$ of RPMI 1640 medium containing $10 \%$ newborn calf serum in 24-well plates at a number of $8 \times 10^{4}$ hepatocytes per well. They were allowed to adhere to culture plates for $5 \mathrm{hr}$ before the medium was exchanged for RPMI 1640 medium without serum. TNF or anti-CD95 was added $30 \mathrm{~min}$ after the medium change. GalN ( $5 \mathrm{mM}$ ) or ActD (333 $\mathrm{nM}$ ) was added directly after the medium change. Unless otherwise indicated experiments were carried out for the times indicated at $37^{\circ} \mathrm{C}$ in an atmosphere composed of $5 \% \mathrm{CO}_{2} / 40 \% \mathrm{O}_{2} / 55 \% \mathrm{~N}_{2}$.

\section{DNA Fragmentation and Cytotoxicity}

Lactate dehydrogenase (48) was determined in culture supernatants (S), and in the remaining cell monolayer $(\mathrm{C})$ after lysis with $0.1 \%$ Triton $\mathrm{X}-100$. The percentage of lactate dehydrogenase release was calculated from the ratio of $\mathrm{S} /(\mathrm{S}+$
C). Alternatively, the capacity to produce formazan from MTT was measured according to the method of Mosmann (49) essentially as described recently (8). Routinely, cytotoxicity was measured in parallel assays using lactate dehydrogenase (LDH) release and MTT reduction as readouts. The correlation of the two methods was $\mathbf{9 7 \%}$. In Results below only one representative set of data from either method is presented. Hepatocytolysis in vivo was determined by measuring the plasma activities of ALT, aspartateaminotransferase, and sorbitol dehydrogenase (48). DNA fragmentation in hepatocyte cultures or in murine livers was quantitated by measuring cytosolic oligonucleosome-bound DNA using an ELISA-kit (Boehringer, Mannheim, Germany) as described (8). As antigen source we employed either the cytosolic fraction $(13000 \times g$ supernatant) of about 150 cultured hepatocytes or the cytosolic fraction from about $75 \mu \mathrm{g}$ of liver tissue. DNA fragmentation was also analyzed semiquantitatively after extraction of low molecular weight DNA from the $13000 \times g$ supernatant of about $50 \mathrm{mg}$ of liver tissue or $2 \times 10^{5}$ cultured hepatocytes by the phenol/chloroform method, precipitation by ethanol and electrophoresis on $1.0 \%$ agarose gels $(50)$.

\section{Morphology}

Livers were fixed for histological examination with $4 \%$ formaldehyde and imbedded in paraplast. Sections $(3-5 \mu \mathrm{m})$ were stained with hematoxylin/eosin and photographed at 1008-fold magnification. Liver cell cultures were either stained directly with $8 \mu \mathrm{g} / \mathrm{ml} \mathrm{H}-33258$ or $5 \mu \mathrm{g} / \mathrm{ml}$ propidium iodide for $3 \mathrm{~min}$, or they were fixed with $80 \%$ methanol $\left(-20^{\circ} \mathrm{C}\right)$ and then stained. Apoptotic nuclei were quantitated under the fluorescence microscope.

\section{Statistics}

Data are expressed as means $\pm \mathrm{SD}$. All cell culture experiments were repeated in at least three different cell preparations. For comparative experiments ( $w t$ hepatocytes versus hepatocytes from genetically altered animals) cells from two mice from different strains were prepared within $\mathrm{l} \mathrm{hr}$ and incubated simultaneously. Statistical differences were determined by an unpaired $t$ test if applicable or with the unpaired Welch test (in the case of inhomogeneous variances). 


\section{RESULTS}

\section{Hepatocytotoxicity and DNA Fragmentation Caused by Anti-CD95 or TNF in Liver Cell Cultures from Wild-Type Mice}

Hepatocyte cultures derived from BALB/c mice were used to determine whether the activation of either CD95 or TNF-RI was sufficient to induce apoptotic cell death. In agreement with our previous study (8), TNF initiated early DNA fragmentation followed several hours later by cell lysis, provided that transcription had been arrested with ActD (Fig. 1). Exposure of mouse hepatocytes to anti-CD95, however, caused hepatocytotoxicity in the absence of transcriptional inhibitors. The type of cell death caused by
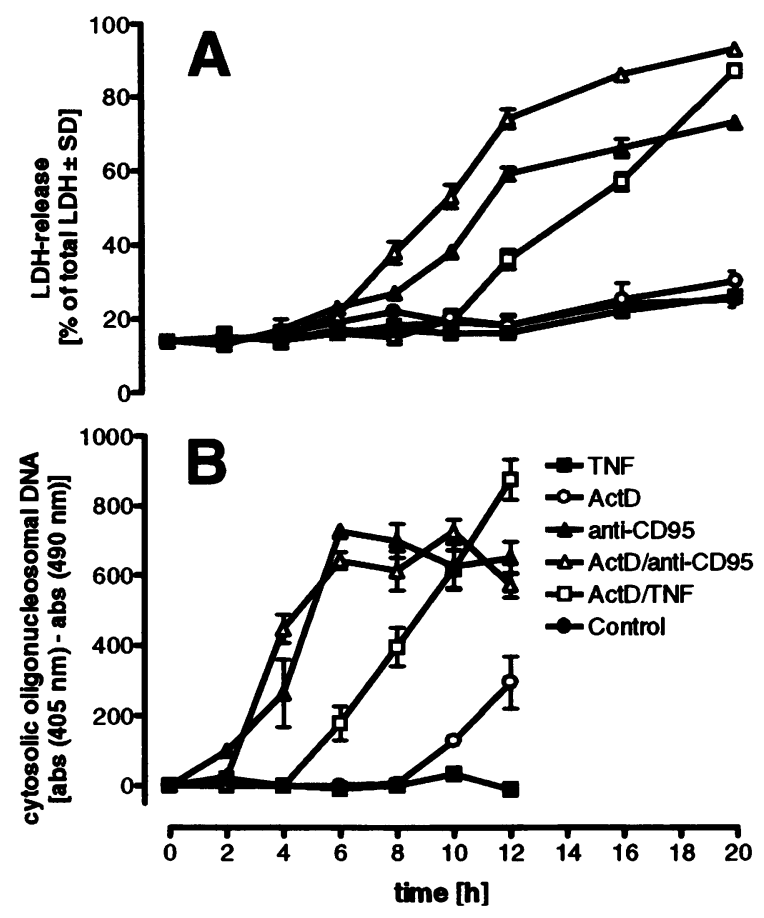

FIG. 1. Time course of DNA fragmentation and cell lysis in murine hepatocytes exposed to anti-CD95 or TNF in the presence or absence of ActD

Hepatocytes from BALB/c mice were incubated in RPMI 1640 without further additions, or with $333 \mathrm{nM}$ ActD, $100 \mathrm{ng} / \mathrm{ml}$ TNF, $100 \mathrm{ng} / \mathrm{ml}$ antiCD95, or combinations of ActD and TNF or antiCD95. After the indicated time periods, LDH release (A) and DNA fragmentation (B) were determined. DNA fragmentation is given as the original absorbance minus the average absorbance of untreated control cells. Data are means of triplicate determinations $\pm \mathrm{SD}$.
CD95 stimulation was apoptotic, as determined by morphological criteria. The time course for LDH release, formation of nuclei with condensed chromatin, and DNA fragmentation in hepatocyte cultures exposed to anti-CD95 revealed that apoptosis and oligonucleosomal DNA cleavage occurred before loss of membrane integrity. The onset of DNA fragmentation in the presence of anti-CD95 was more rapid than in TNF-challenged cells and clearly preceded cell lysis. These findings suggested that agonist binding to CD95 on hepatocytes is sufficient to directly cause apoptosis in this cell type.

Next, the concentration-dependence of CD95-mediated hepatocyte killing and its modulation by various culture conditions were examined (Fig. 2). The presence of transcriptional inhibitors such as GalN or ActD significantly increased the extent of cell damage caused by antiCD95 without causing a significant shift of the concentration response curve to the left. Simultaneous administration of TNF and anti-CD95 to hepatocyte cultures sensitized with ActD caused additive toxicity rather than a synergistic effect (Fig. $2 \mathrm{~B}$ and D). The median cytotoxic concentration $\left(\mathrm{LC}_{50}\right)$ of anti-CD95 was in the range of $8-25 \mathrm{ng} / \mathrm{ml}$, irrespective of the amount of TNF- $\alpha$ present. Varying between individual cell preparations, maximum toxicity was obtained using $50-300 \mathrm{ng} / \mathrm{ml}$ anti-CD 95 .

The difference in sensitivity to the enhanced toxicity caused by transcriptional inhibitors (i.e., more than 1000-fold sensitization for TNF compared with a maximum 2-fold sensitization for anti-CD95) suggests that different intracellular mechanisms are involved in the initiation of cell death by CD95 stimulation and by TNF-R1 activation. This notion is further substantiated by the finding that the two pathways leading to hepatocytotoxicity were differentially influenced by the oxygen tension to which the cells were exposed (Fig. $2 \mathrm{~A}$ and $\mathrm{C}$ ). Culturing hepatocytes under our standard conditions of $400 \mathrm{hPa}$ oxygen in the incubator resulted in a significantly higher TNF toxicity compared with that in cultures incubated under a 200-hPa oxygen atmosphere. In anti-CD95-challenged hepatocytes we did not observe a significant influence by the oxygen tension on toxicity, whether or not transcriptional inhibitors were present. Thus, mechanisms of cell death in these two models have a different dependence on the availability of oxygen. 



FIG. 2. Comparison of the concentration dependence of the toxicity of combinations of anti-CD95 and TNF under different culture conditions

Hepatocytes from BALB/c mice were left to adhere to culture plates for $6 \mathrm{hr}$ in a 400-hPa athmosphere. Then medium was substituted for by pure RPMI1640 containing $333 \mathrm{nM}$ ActD and various concentrations of murine TNF- $\alpha$ or human TNF- $\beta$ (A), 333 nM ActD and various concentrations of anti-CD95 with murine TNF- $\alpha$ (B), anti-CD95 in combination with $5 \mathrm{mM}$ GalN or $333 \mathrm{nM}$ ActD (C), or $333 \mathrm{nM}$ ActD and murine TNF- $\alpha$ in combination with various concentrations of anti-CD95 (D). Incubations were continued at $400 \mathrm{hPa}$ oxygen for $20 \mathrm{hr}$ (B and D), or parallel incubations were continued at 200 and $400 \mathrm{hPa}$ oxygen (A and C) for $20 \mathrm{hr}$, before cytotoxicity was determined by the measurement of LDH release. Data are means $\pm \mathrm{SD}, n=3$.

The Interrelationship between CD95 Expression and TNF-Induced Hepatocyte Apoptosis in Vitro

In order to determine whether TNF would still cause apoptosis in hepatocytes lacking functional CD95, hepatocytes isolated from $l p r$ mice were used. These hepatocyte cultures were incubated with anti-CD95, with or without ActD, to ensure that there was no leaky expression of functional CD95. lpr hepatocytes were completely resistant to an anti-CD95 concentration that was highly toxic to control cells (Fig. 3A). They proved, 

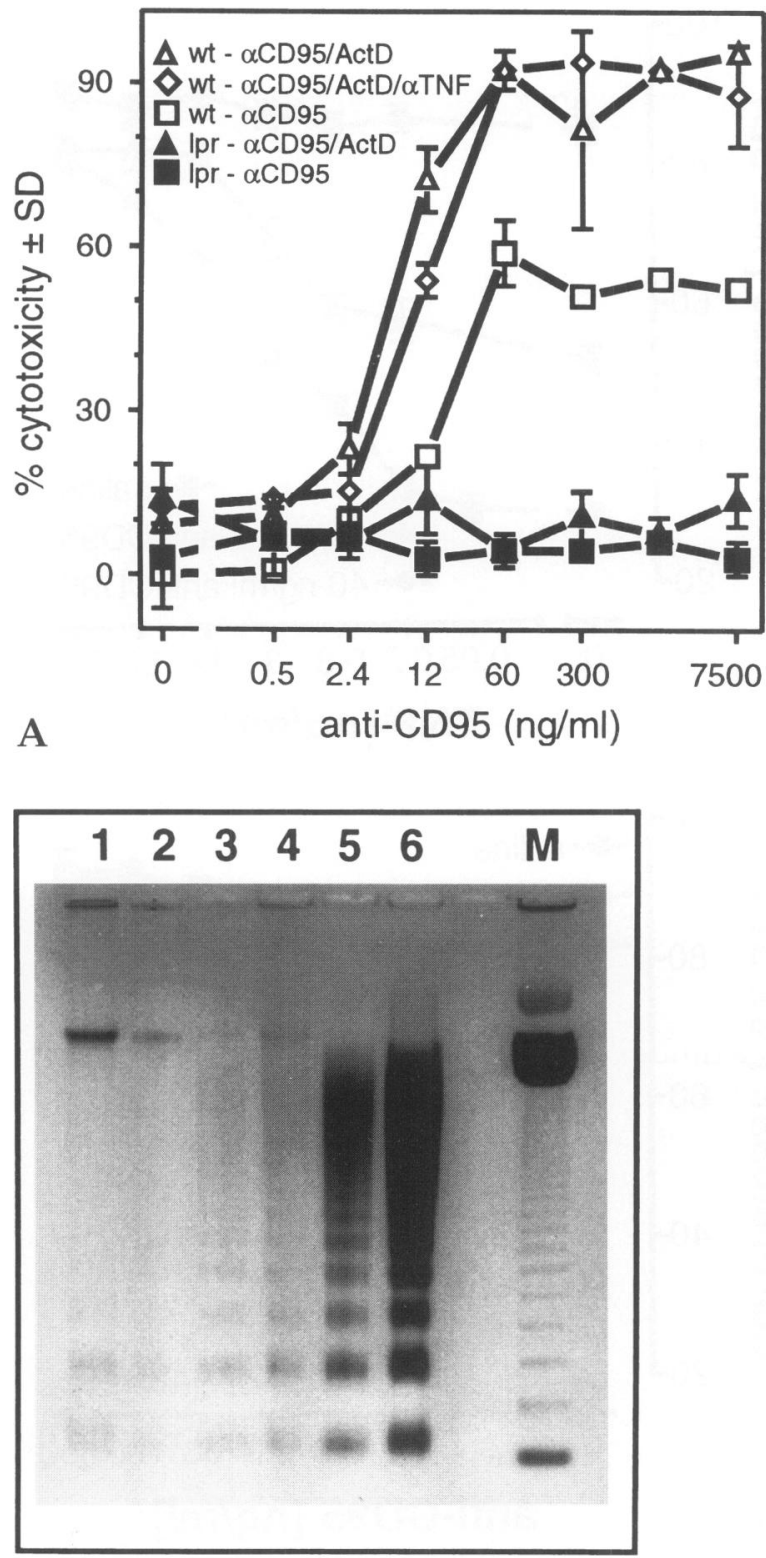

C

however, to be sensitive to incubation with a combination of TNF and ActD. There was no significant difference in the sensitivity towards TNF-induced killing over a large range of concentrations for cell preparations deriviu from either $w t$ or lpr mice (Fig. 3B). In addition, cytosolic DNA extracted from ActD/TNF-treated hepatocytes derived from either substrain showed a typical DNA ladder pattern suggestive of apoptotic DNA fragmentation (Fig. 3C). Incubation of $l p r$ hepatocytes with anti-CD95 caused neither any detectable DNA fragmentation nor significant cytotoxicity. We conclude, therefore,

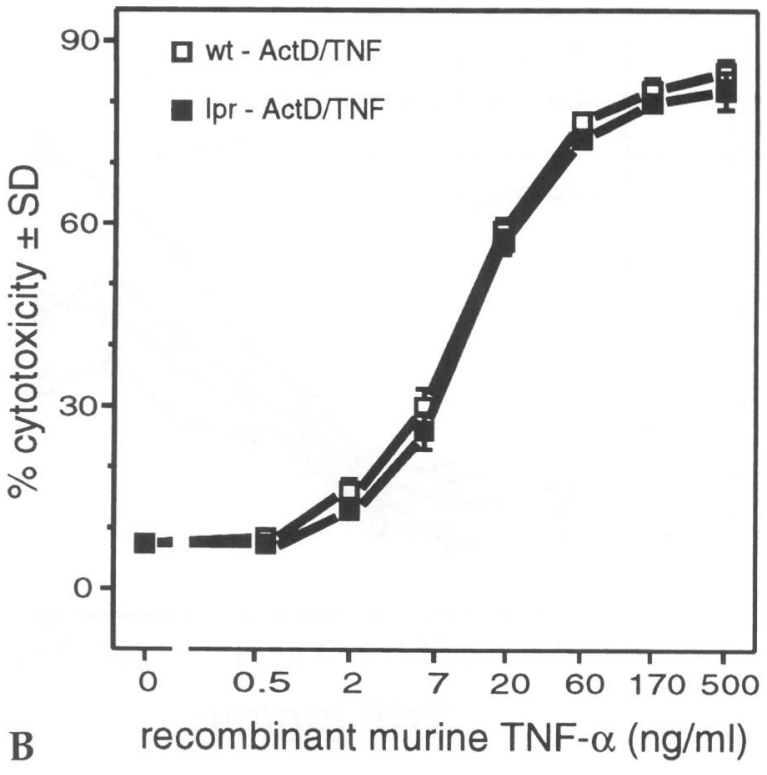

FIG. 3. Toxicity and DNA fragmentation initiated by TNF or anti-CD95 in hepatocyte cultures from wt or $l p r$ MRL/MpJ mice

(A) Hepatocytes were incubated with or without $333 \mathrm{nM}$ ActD and with various concentrations of anti-CD95. Viability was measured after $20 \mathrm{hr}$ by quantitation of formazan forming capacity. Neutralizing anti-TNF antibody ( $\alpha$ TNF) was added at a dilution of 1:200. (B) Hepatocytes were incubated with $333 \mathrm{nM}$ ActD and various concentrations of TNF before toxicity was determined after $20 \mathrm{hr}$. All data are means $\pm \mathrm{SD}, n=3$. (C) Hepatocytes were incubated for $10 \mathrm{hr}$ before they were lysed for DNA extraction. DNA was analyzed on $1 \%$ agarose gels and stained with ethidium bromide. (Lane 1) control-lpr. (Lane 2) control-wt. (Lane 3) ActD-lpr. (Lane 4) ActD-wt. (Lane 5) ActD/TNF (100 ng/ml)-wt. (Lane 6) ActD/ TNF-lpr. M, $n \times 123$ bp molecular weight marker.

that the presence of functional CD95 on hepatocytes is not required for TNF-induced hepatocyte apoptosis.

\section{The Role of CD95 Expression in TNF-Induced Hepatic Failure in vivo}

Subsequent experiments examined whether the findings from the in vitro studies translated to the in vivo situation. First, we confirmed the findings by Ogasawara et al. (22) that $l p r$ mice are resistant to anti-CD95-induced liver failure. In agreement with our results in hepatocyte cul- 


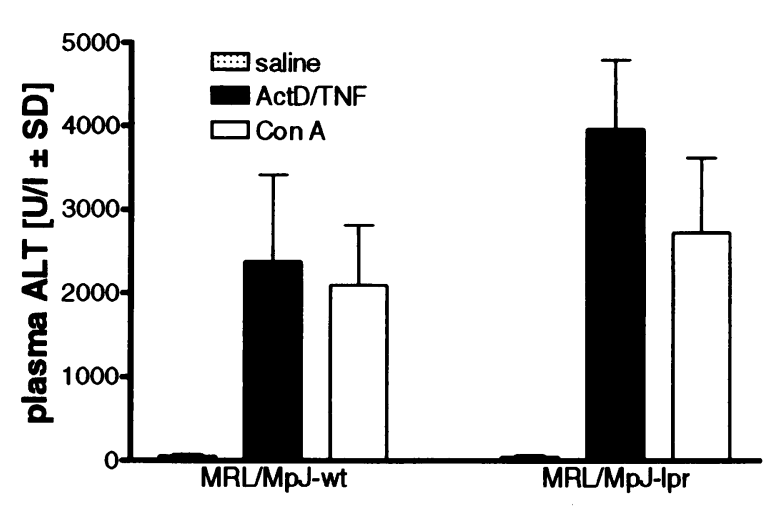

FIG. 4. Hepatotoxicity of Con A or ActD/TNF in wt or lpr MRL/MpJ mice

Animals were injected intravenously with $25 \mathrm{mg} / \mathrm{kg}$ Con A or saline or a combination of $3.3 \mu \mathrm{g} / \mathrm{kg}$ TNF i.v. with $800 \mu \mathrm{g} / \mathrm{kg}$ ActD i.p. Hepatotoxicity was determined after $8 \mathrm{hr}$ by the measurement of plasma ALT in blood obtained by cardiac puncture. Data are means $\pm \mathrm{SD}, n=3$.

tures, we found that both $l p r$ mice and $w t$ animals sensitized with ActD developed liver failure following TNF injection (Fig. 4). These results were confirmed using an alternative TNF-dependent model of inflammatory liver failure that uses T-cell activation by concanavalin A (Con A) as an initiating stimulus and does not require additional transcriptional sensitizers $(35,36)$. Intravenous injection of the T-cell mitogen Con A caused a systemic release of similar amounts of TNF in both $w t$ and $l p r$ mice $(340 \pm 85 \mathrm{pg}$ TNF $/ \mathrm{ml}$ and $275 \pm 45 \mathrm{pg} \mathrm{TNF} / \mathrm{ml}$, respectively). The extent of liver damage observed was not significantly different between mice from the two substrains (Fig. 4). Passive immunization of $w t$ or $l p r$ mice against TNF completely inhibited any Con A-induced ALT release (data not shown). These findings support the conclusion that the susceptibility of CD95-deficient mice to TNF-dependent inflammatory liver failure is unaltered. From these observations we conclude that in vivo and in vitro TNF-induced hepatocyte apoptosis is a pathological event independent of CD95 expression.

\section{The Role of TNF-R1 in CD95-Induced Hepatocyte Apoptosis in Vitro}

In order to determine whether TNF-R 1 played a role in hepatocyte killing by CD95 activation, we isolated hepatocytes from TNF-Rl-deficient $\left(\right.$ tnf- $\left.r 1^{\circ}\right)$ mice (45). These mice were completely resistant to TNF-induced apoptosis, with or with- out sensitization by ActD (this study and Ref. 8). Hepatocytes isolated from these mice allowed us to study the independent effects of CD95 activation on programmed cell death in hepatocytes.

We first checked whether TNF would modify anti-CD95 toxicity in nonsensitized hepatocytes from $w t \mathrm{C} 57 \mathrm{Bl} / 6$ mice. Different concentrations of anti-CD95 induced cell death to different levels, which were, however, not influenced by the presence of TNF over a wide range of concentration (Fig. 5A). The concentration-response curve of anti-CD95 in hepatocytes from $w t$ mice was similar to that in cells from $t n f-r 1^{\circ}$ mice. In addition, the toxicity of anti-CD95 was influenced neither by the presence of high concentrations of TNF nor by the simultaneous addition of neutralizing anti-TNF antibodies (Fig. 5B). Finally, we studied anti-CD95 toxicity in hepatocytes from both substrains when transcriptional inhibitors were present. As described previously (8), ActD alone had a higher basal toxicity in $w t$ hepatocytes as compared to $\operatorname{tnf}-r 1^{\circ}$ cells. This could be due to endogenously released TNF, since this basal toxicity was reduced by cotreatment with neutralizing anti-TNF antibodies. Although the maximum damage induced by anti-CD95 was similar in $w t$ and $\operatorname{tnf}-r l^{\circ}$ hepatocytes with or without transcriptional inhibitors, a small but consistent difference in sensitivity to toxicity was observed (Fig. 5C). wt hepatocytes exhibited a seemingly 2 -fold lower $\mathrm{LC}_{50}$ to anti-CD95 when sensitized with ActD or GalN. This may be due to a different basal viability and therefore a higher susceptibility to damage by additional stimuli of these cells, which are highly sensitive even to trace concentrations of TNF, rather than due to a direct interaction of anti-CD95 with TNF-R1.

In order to verify the apoptotic nature of CD95-induced cell death in tinf- $r l^{\circ}$-deficient hepatocytes, we measured DNA fragmentation 6 hr after incubation with anti-CD95, at a time when no significant cell lysis had occurred. We observed typical oligonucleosomal DNA-fragmentation in both $w t$ and $t n f-r l^{\circ}$ hepatocytes (Table 1). Taken together, these data suggest that neither is TNF-Rl activation required as a costimulatory signal nor is it directly involved in CD95-induced hepatocyte apoptosis.

\section{CD95-Induced Hepatocyte Apoptosis in Vivo and Its Relation to TNF-R I Expression}

In TNF-dependent models of inflammatory liver failure, DNA-fragmentation and morphological 


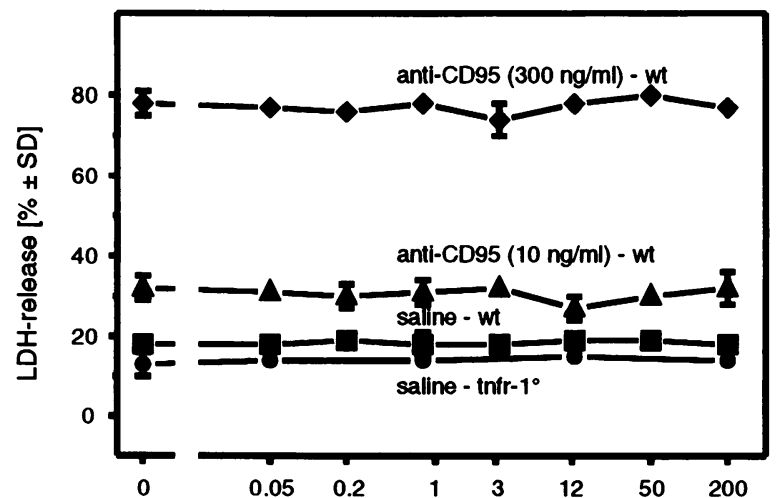

A

recombinant murine TNF- $\alpha[\mathrm{ng} / \mathrm{ml}]$

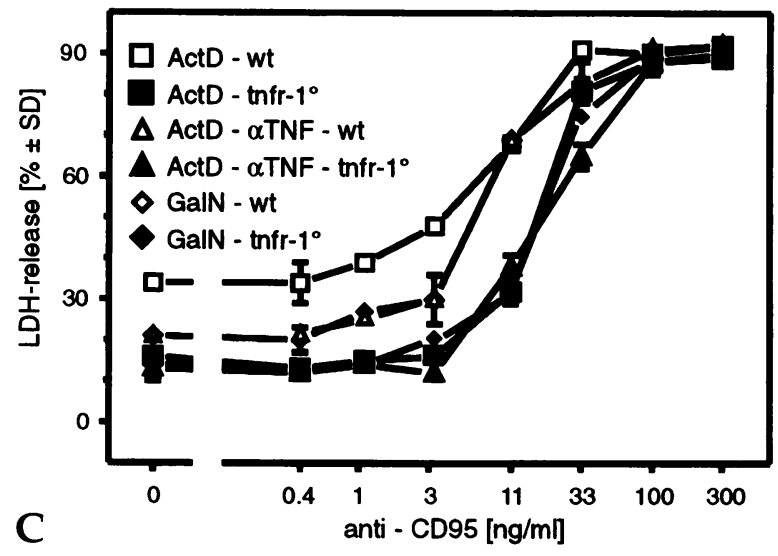

appearance of apoptosis preceded hepatocyte lysis. We thus determined whether this was also true following challenge of mice with anti-CD95. Time course analysis of DNA fragmentation and ALT release (a parameter of cell lysis) showed that in the CD95 model there also was an early

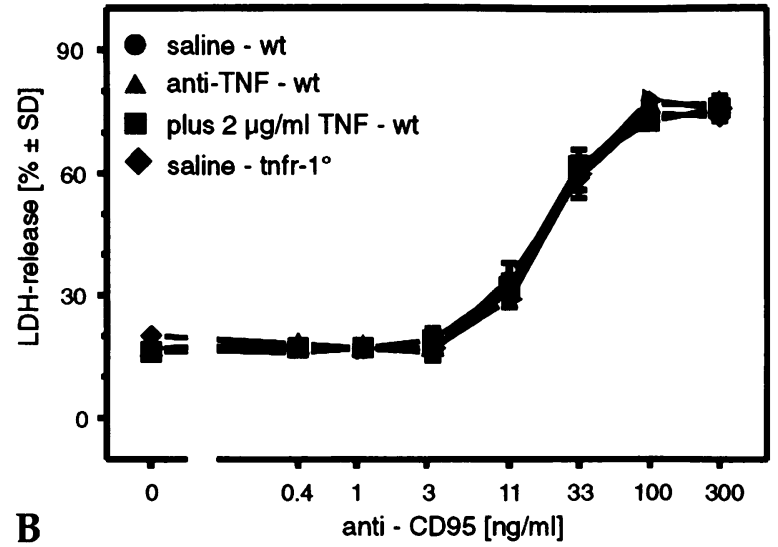

FIG. 5. Toxicity initiated by combinations of TNF and anti-CD95 in hepatocyte cultures from $w \boldsymbol{t}$ or $\boldsymbol{t} \boldsymbol{n f}-\boldsymbol{r} \mathbf{1}^{\circ} \mathrm{C} 57 \mathrm{Bl} / 6 \mathrm{mice}$

(A) Hepatocytes were incubated for $20 \mathrm{hr}$ with different combinations of TNF and anti-CD95. (B) Hepatocytes were incubated for $20 \mathrm{hr}$ with antiCD95 alone or in combination with $2 \mu \mathrm{g} / \mathrm{ml}$ TNF or 1:200 neutralizing anti-TNF antibody (anti-TNF). (C) Hepatocytes were sensitized with $5 \mathrm{mM}$ GalN or 333 $\mathrm{nM}$ ActD and then incubated with anti-CD95 for 20 hr. Neutralizing anti-TNF antibody ( $\alpha \mathrm{TNF}$ ) was used at a 1:200 dilution. All data are means \pm SD from triplicate determinations.

increase of DNA fragmentation followed later by cell lysis (Fig. 6A). Fragmented DNA was confirmed to consist of the typical oligonucleosomal pattern by agarose gel electrophoresis (Fig. 6B). In this respect, the findings are similar to the TNF-dependent model, however no sensitization

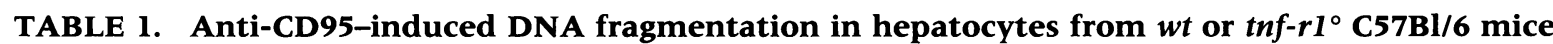

Hepatocyte DNA-Fragmentation ( $\%$ of saline-treated control \pm SD) ${ }^{a}$

\begin{tabular}{ccccc}
\hline \multicolumn{2}{c}{ No Pretreatment } & & \multicolumn{2}{c}{ Pretreatment with 5 mM GalN } \\
\cline { 5 - 5 } Saline & Anti-CD95 & & Saline & Anti-CD95 \\
\cline { 5 - 5 } $100 \pm 27$ & $330 \pm 23$ & & $117 \pm 21$ & $340 \pm 29$ \\
$100 \pm 16$ & $570 \pm 34$ & $95 \pm 2$ & $540 \pm 19$
\end{tabular}

${ }^{a}$ Eighty thousand hepatocytes plated in 24 -well plates in $200 \mu \mathrm{l}$ of medium were pretreated with $5 \mathrm{mM}$ GalN or saline for 30 min, before they were challenged with $100 \mathrm{ng} / \mathrm{ml}$ anti-CD95 or solvent control. After $6 \mathrm{hr}$, cells were lysed. Low molecular weight DNA was prepared by centrifugation and subsequently analysed in an ELISA determining the amount of cytosolic oligonucleosomal DNA. 

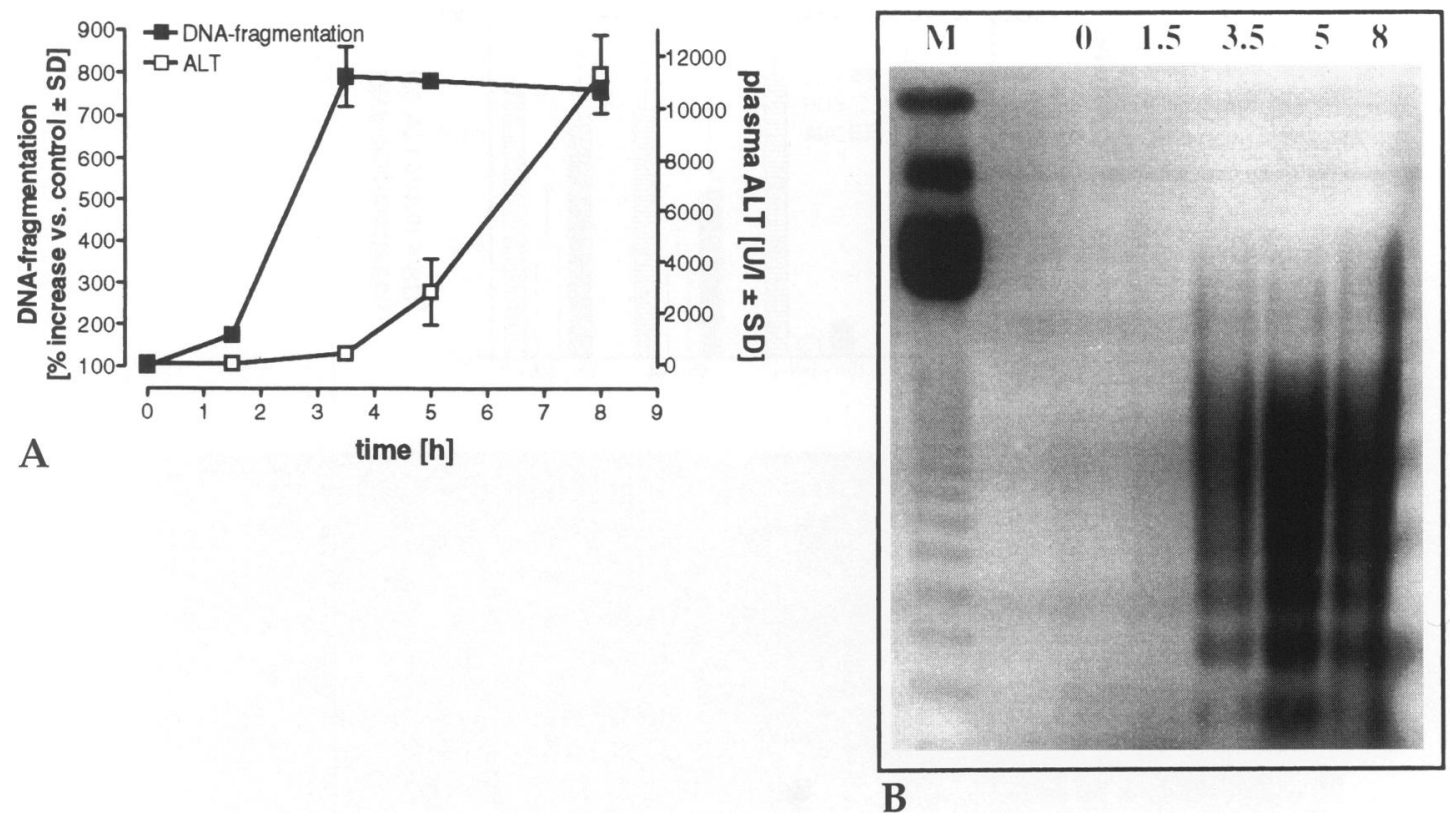

FIG. 6. Time course of hepatic DNA fragmentation and ALT release from livers of BALB/c mice treated with anti-CD95

Mice were injected intravenously with $2 \mu \mathrm{g}$ anti-CD95. At the time points indicated, blood was withdrawn by cardiac puncture for the determination of plasma ALT (A) and the livers were homogenized for the preparation of DNA for the ELISA (A) and for agarose gel electrophoresis (B). Data are means $\pm \mathrm{SD}, n=3$. The superscripts to the lanes on the gel stand for the time period following anti-CD95 injection after which hepatic low molecular weight DNA was prepared.

by transcriptional block was required and passive immunization of mice against TNF did not modify the toxicity of anti-CD95 in vivo (data not shown).

In order to confirm the in vitro findings obtained using $\operatorname{tnf}-r 1^{\circ}$ hepatocytes, the sensitivities of $w t$ and $t n f-r 1^{\circ}$ mice to CD95 activation and to the TNF-inducing inflammogen Con A were determined. Con A injection $(25 \mathrm{mg} / \mathrm{kg})$ caused systemic TNF release ( $w t: 187 \pm 34 \mathrm{pg} / \mathrm{ml}$; $\operatorname{tnf}-r 1^{\circ}: 328 \pm 160 \mathrm{pg} / \mathrm{ml}$ ) in both mouse substrains. Significant $(p<0.05, n=7)$ hepatotoxicity was, however, only induced in $w t$ mice (ALT: $1853 \pm 856 \mathrm{U} / \mathrm{l}$ ), whereas tnf- $r 1^{\circ}$ mice were not affected (ALT: $99 \pm 22 \mathrm{U} / \mathrm{l}$ ). In contrast, following challenge with anti-CD95 there were no significant differences between the two substrains with respect to time course and to the extent of DNA fragmentation and cell lysis (Fig. 7A). In addition, histological examination showed that early hepatocyte apoptosis was present in livers from either mouse substrain (Fig. $7 \mathrm{~B}$ and C). Only $5 \mathrm{hr}$ after anti-CD95 injection, there was a massive increase in DNAcontaining intracellular and extracellular apop- totic bodies and hyperchromatic marginated chromatin in hepatocyte nuclei $(20 \%$ of all hepatocytes). These histological signs of apoptosis were even more pronounced than those found after TNF injection into GalN-sensitized $w t$ mice (41). There was no significant infiltration of leukocytes, but a strong intra- and extra-sinusoidal accumulation of erythrocytes. These results are consistent with the in vitro experiments described above and in agreement with the data published by Ogasawara et al. (22). The findings strongly suggest that CD95 activation or TNF-R 1 stimulation represent two independent pathways resulting in liver cell apoptosis.

\section{Different Modulation of Anti-CD95-induced Liver Injury Compared with That Observed in TNF-Dependent Models}

The induction of anti-CD95-induced hepatotoxicity did not require pretreatment of mice with ActD or GalN. However, as shown in Fig. 8, the dose-response curve was shifted to the left by approximately a factor of two when GalN was 

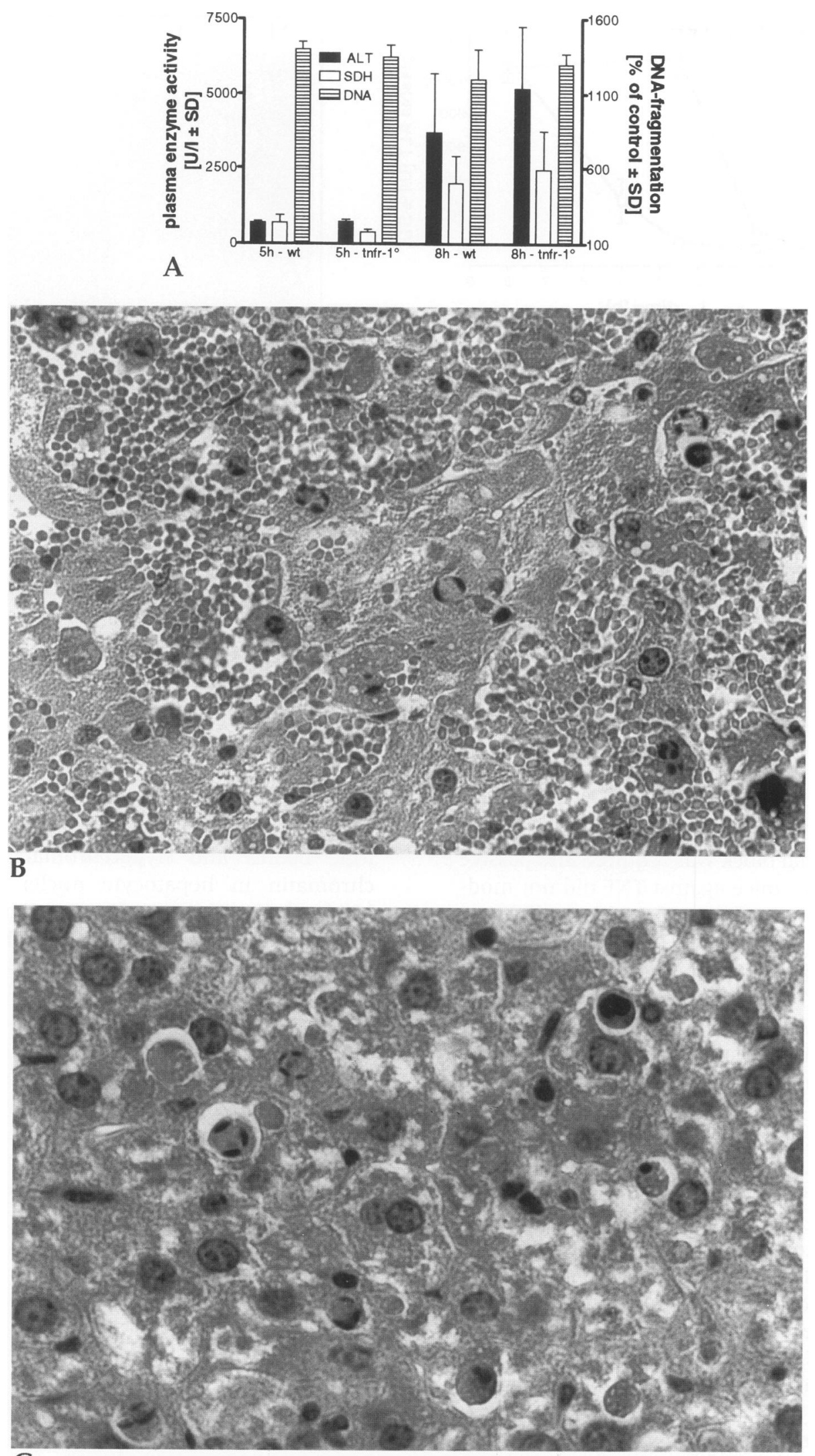

C 
FIG. 7. Comparison of apoptosis, DNA fragmentation, and cell lysis in livers from $w t$ or $\operatorname{tnf}-r 1^{\circ} \mathrm{C} 57 \mathrm{Bl} / 6$ mice

(A) Six mice from each substrain were injected intravenously with $2 \mu \mathrm{g} /$ mouse anti-CD95. After 5 or 8 hr three animals from each substrain were terminally anesthesized. Blood was withdrawn into heparinized syringes for the determination of ALT and sorbitol dehydrogenase (SDH), and livers were excised for the determination of DNA fragmentation. Three untreated control mice were killed after the same time periods as a control for hepatic DNA fragmentation. They had normal levels of ALT $(70 \mathrm{U} / \mathrm{l})$ or SDH $(15 \mathrm{U} / \mathrm{l})$. (B) Histological evidence of apoptosis and severe hemorrhage $5 \mathrm{hr}$ after the injection of anti-CD95. The specimen was stained with hematoxilin/eosin and photographed at an initial magnification of $400 \times$. Numerous apoptotic bodies and cells with strongly marginated and condensed chromatin are seen. (C) Liver tissue $5 \mathrm{hr}$ after injection of anti-CD95, photographed at an original magnification of $630 \times$. Apoptotic hepatocyte death occurs in the absence of infiltrating inflammatory cells.

administered simultaneously. This is in strong contrast to the 1,000- to 10,000-fold sensitization by GalN observed in the TNF-mediated models. This lack of sensitization by GalN is also a strong argument against a possible endotoxin contamination of the anti-CD95 preparation as a cause for its hepatotoxicity. Such contamination is a major problem in investigations of inflammogens in vivo, since even trace amounts of endotoxin strongly enhance TNF toxicity. We therefore addressed this problem by comparing the hepatotoxicity of anti-CD95 in LPS-sensitive $\mathrm{C} 3 \mathrm{H} / \mathrm{HeN}$ and LPS-resistant $\mathrm{C} 3 \mathrm{H} / \mathrm{HeJ}$ mice. We found no significant difference between the sensitivity of these two strains to anti-CD95 (Table 2). and anti-CD95 injection did not cause systemic TNF release.

Finally, we examined whether pre-treatment of mice with IL-1, which is known to pre-

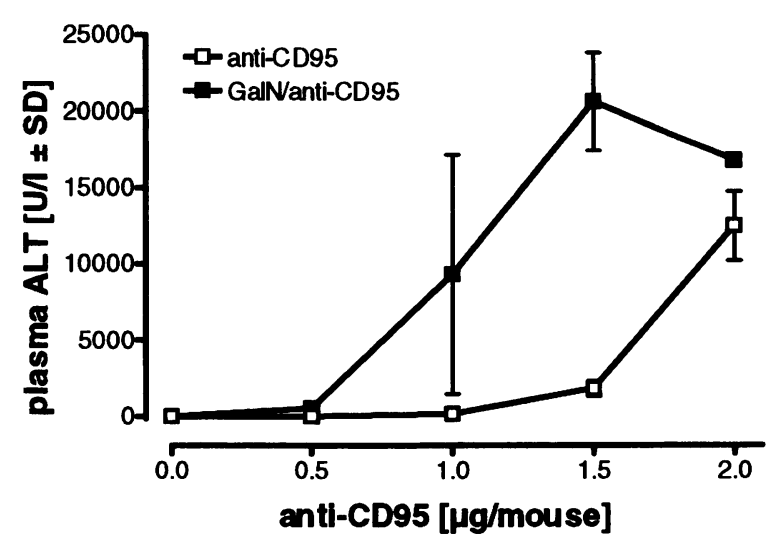

FIG. 8. Dose-toxicity comparison in antiCD95-challenged BALB/c mice treated with or without GalN

Mice were injected intravenously with different doses of anti-CD95 with or without $700 \mathrm{mg} / \mathrm{kg}$ GalN i.p. Plasma ALT was determined after $8 \mathrm{hr}$. Data are means $\pm \mathrm{SD}, n=3$. vent completely TNF-induced toxicity and DNA fragmentation via the induction of tolerance (41), had a similar effect in the anti-CD95 model. There was no significant reduction of liver damage (Table 1), although IL-1 was effective against TNF in parallel experiments (data not shown). This absence of a cross-tolerance induction by IL-1 suggests that independent mechanisms are involved in hepatocyte apoptosis due to antiCD95 and TNF.

\section{DISCUSSION}

Agonist stimulation of CD95 plays an important role in cellular immunity (3). In addition, CD95 activation has been suggested to have pathological relevance for liver disease, since agonistic anti-CD95 Ab treatment caused fulminant liver failure in mice (22) and apoptotic murine hepatocyte death in vitro (6). In these earlier studies, temporal and quantitative relationships between cell lysis and apoptotic markers such as DNA fragmentation were not examined. Also, the interrelationships among TNF and its receptors and CD95-signaled hepatocytotoxicity remained open. Finally, anti-CD95 toxicity in the absence of additional sensitization of cells by ActD had not been demonstrated in the previous study by Ni et al. (6).

Here we presented direct evidence that CD95 stimulation on isolated liver cells is sufficient to induce apoptotic cell death; in other words, that nonsensitized hepatocytes are the immediate target affected by the CD95 system. In similar fashion to TNF-induced hepatocyte death, activation of CD95 caused DNA fragmentation which preceded cell lysis by several hours. There were, however, marked differences between TNF- and anti-CD95-induced toxicity: first, CD95-mediated cell death was faster than TNF-induced cell 
TABLE 2. Modulation of liver damage in mice treated with $2 \mu \mathrm{g} / \mathrm{mouse}$ anti-CD95

\begin{tabular}{|c|c|c|c|}
\hline Mouse Strain & Pretreatment & $\operatorname{ALT}(\mathbf{U} / \mathbf{l} \pm \mathbf{S D})^{a}$ & $\begin{array}{l}\text { DNA Fragmentation } \\
(\% \text { of control } \pm \text { SD })^{a}\end{array}$ \\
\hline $\mathrm{C} 3 \mathrm{H} / \mathrm{HeN}$ & - & $11780 \pm 4570$ & $1730 \pm 160$ \\
\hline $\mathrm{C} 3 \mathrm{H} / \mathrm{HeJ}$ & - & $10350 \pm 2060$ & $720 \pm 60$ \\
\hline $\mathrm{BALB} / \mathrm{c}$ & - & $19810 \pm 1380$ & $430 \pm 25$ \\
\hline $\mathrm{BALB} / \mathrm{c}$ & IL- $1^{b}$ & $11800 \pm 1075$ & $407 \pm 20$ \\
\hline
\end{tabular}

death. Second, sensitization of cells was not a prerequisite for killing by anti-CD95, while it was a necessary metabolic condition for TNFinduced hepatocyte apoptosis (21). Preincubation of hepatocytes with ActD had a significant influence neither on the concentration dependency nor on the time course of anti-CD95induced cell lysis or DNA fragmentation. The only parameter affected by ActD was the relative size of the population of hepatocytes killed by anti-CD95 treatment, since the maximum obtainable cytotoxicity was increased from $60-70 \%$ in cell cultures stimulated with anti-CD95 only to $80-95 \%$ in cells incubated with anti-CD95 plus ActD. Third, anti-CD95- and TNF-induced hepatocyte apoptosis were modulated differently by the ambient oxygen concentration. Switching oxygen partial pressure from 400 to $200 \mathrm{hPa}$ reduced TNF toxicity, but did not influence antiCD95 toxicity. From these observations, we conclude that the nature of the mechanisms that finally result in cell death of anti-CD95- or TNFchallenged hepatocytes is different.

In addition to the characterization of the types and modalities of cell death due to TNF-R 1 or CD95 stimulation, the hepatocyte culture system was used for the examination of putative interactions of TNF-Rl and CD95. For this purpose, we used hepatocytes from $w t$ mice stimulated with a combination of TNF and anti-CD95 and hepatocytes from mice lacking either TNF-R1 or functional CD95. Although it has been noted before that $l p r$ mice are protected against anti-CD95 toxicity (22), it has also been shown that CD95 expression in these mice may not be completely absent (51). We demonstrated that liver cells derived from such mice are completely resistant towards agonist stimulation of
CD95, even after sensitization with ActD. We therefore assume that in lpr mice CD95 expression is either absent or does not exert its normal function in liver tissue. Using these $l p r$ mice, we showed that TNF toxicity is not modulated by CD95. In a complementary experiment, utilizing hepatocyte cultures from tnf- $r 1^{\circ}$ mice, we found that anti-CD95 toxicity is not modulated by TNF$\mathrm{R}$ l. In an additional set of experiments, we investigated whether stimulation of either one of the two cell death transmitting receptors may influence the toxicity due to stimulation of the other. We did not find any evidence for this and concluded that stimulation of either anti-CD95 or TNF-R1 in hepatocytes represents one of two independent pathways for inducing apoptosis.

The key findings in our in vitro experiments were subsequently shown to also apply to the in vivo situation. As hepatic DNA fragmentation was caused by anti-CD95 or TNF stimulation of hepatocytes in vivo and in vitro, and DNA cleavage preceded cell lysis and subsequent liver failure in both models, it was concluded that hepatocyte apoptosis is an early pathological event that is causally involved in subsequent fulminant liver failure. By utilizing $l p r$ and $t n f r-1^{\circ}$ mutant mice with different genetic backgrounds, we were able to show in three different experimental models of inflammation (generated by injection of Con A and anti-CD95 in nonsensitized mice and by TNF injection in ActD-sensitized mice) that CD95 and TNF-RI cause hepatic failure independently of each other.

Two independent pathways regulating hepatocyte apoptosis via the stimulation of two different members of the TNF-R/nerve growth factor receptor family seem to exist (Fig. 9). Hepatocyte apoptosis occurring under patholog- 




FIG. 9. Two possible independent pathways triggering hepatic apoptosis

ical or physiological conditions would involve either one of these pathways; it would thus seem mandatory to examine simultaneously the involvement or activation of both pathways in descriptive and analytical studies.

The common link between the T cell-dependent models, such as using Con $\mathrm{A}$ as a polyclonal stimulator, and models involving macrophage activation by immunostimulants such as LPS, is the systemic release and the distal toxic action of TNF. The role of CD95L in these models is poorly characterized. It has, however, been shown by experimental intervention using either neutralizing anti-TNF antibodies or by deletion of TNF-Rl that hepatotoxicity in these models is explained by the activation of the TNF pathway alone $(8,35,38,45,52-54)$. It remains to be established whether "the CD95 death factor" (3) represents an additional or alternative mechanism of liver dysfunction during a complex event such as shock. Based on the present experimental knowledge, several possibilities for the pathophysiological role of the CD95 system may be envisaged (Fig. 9): (i) Hepatocytes may be killed by soluble systemic CD95L. For instance an increased release of this CD95 agonist from lym- phocytes has been shown during infection with human immunodeficiency virus (HIV) or following incubation with the HIV-encoded tat protein (55). (ii) Hepatocytes may be killed by cell surface CD95L on T cells (56). Since CD95 expression has been associated with human viral hepatitis and fulminant liver failure $(43,44)$, this may represent an endogenous mechanism for the control of viral infection in the liver. (iii) The CD95 pathway may be involved in the control of adaptational liver growth and homeostasis together with TGF- $\beta$ (57) and the activin system (58). Although purely hypothetical, the constitutive presence of functional CD95 on hepatocytes makes such a role of the CD95 receptor ligand system feasible.

TNF and other products from liver nonparenchymal cells have been associated with many different liver diseases and liver toxicity $(59,60)$. The reticuloendothelial system of the liver and especially TNF have been suggested to be involved in liver failure due to xenograft rejection (61), alcohol-induced liver disease (62), viral infection (63), and chemical insult (64-68). The role of CD95, which we have shown to be a potent inducer of apoptosis in nonsensitized hepatocytes in vivo or in vitro, has not been evaluated in this large variety of liver disorders. Since the CD95 system acts independently from TNF and its receptors on hepatocytes, and the activation of the CD95 death pathway seems to follow mechanisms different from those of the TNF system, further investigation of the individual roles of these two apoptosis-mediating systems in liver pathogenesis is warranted.

\section{ACKNOWLEDGMENTS}

The excellent technical assistance of $\mathrm{S}$. Otte and M. Ullmann is gratefully acknowledged. We are indebted to Dr. P.-L. Nicotera (Konstanz) for stimulating discussion. This work was supported by the Deutsche Forschungsgemeinschaft grants We686-15 and Til69/3.

\section{REFERENCES}

1. Yonehara S, Ishii A, Yonehara M. (1989) A cell-killing monoclonal antibody (anti-Fas) to a cell surface antigen co-downregulated with the receptor of tumor necrosis factor. $J$. Exp. Med. 169: 1747-1756.

2. Trauth BC, Clas C, Peters AMJ, et al. (1989) 
Monoclonal antibody-mediated tumor regression by induction of apoptosis. Science 245: 301-305.

3. Nagata S, Golstein P. (1995) The fas death factor. Science 267: 1449-1455.

4. Cleveland JL, Ihle JN. (1995) Contenders in FasL/TNF death signaling. Cell 81: 479-482.

5. Oehm A, Behrmann I, Falk W, et al. (1992) Purification and molecular cloning of the APO- 1 cell surface antigen, a member of the tumor necrosis factor/nerve growth factor receptor family. J. Biol. Chem. 267: 1070910715.

6. Ni R, Tomita Y, Matsuda K, et al. (1994) Fas-mediated apoptosis in primary cultured mouse hepatocytes. Exp. Cell. Res. 215: 332337.

7. Tartaglia LA, Rothe M, Hu Y-F, Goeddel DV. (1993) Tumor necrosis factor's cytotoxicity is signaled by the p55 TNF receptor. Cell 73: 213-216.

8. Leist M, Gantner F, Jilg S, Wendel A. (1995) Activation of the $55 \mathrm{kDa}$ TNF receptor is necessary and sufficient for TNF-induced liver failure, hepatocyte apoptosis, and nitrite release. J. Immunol. 154: 1307-1316.

9. Itoh N, Yonehara S, Ishii A, et al. (1991) The polypeptide encoded by the cDNA for human cell surface antigen Fas can mediate apoptosis. Cell 66: 233-243.

10. Suda T, Nagata N. (1994) Purification and characterization of the Fas-ligand that induces apoptosis. J. Exp. Med. 179: 873-879.

11. Brakebusch C, Nophar Y, Kemper O, Engelmann H, Wallach D. (1992) Cytoplasmic truncation of the p55 tumor necrosis factor (TNF) receptor abolishes signalling, but not induced shedding of the receptor. EMBO J. 11: 943-950.

12. Tartaglia LA, Ayres TM, Wong GHW, Goeddel DV. (1993) A novel domain within the $55 \mathrm{kd}$ TNF recptor signals cell death. Cell 74: 845-853.

13. Song HY, Dunbar JD, Donner DB. (1994) Aggregation of the intracellular domain of the type 1 tumor necrosis factor receptor defined by the two-hybrid system. J. Biol. Chem. 269: 22492-22495.

14. Itoh N, Nagata S. (1993) A novel protein domain required for apoptosis. Mutational analysis of human fas antigen. J. Biol. Chem. 268: 10932-10937.

15. Boldin MP, Mett IL, Varfolomeev EE, et al. (1995) Self-assiciation of the "death domains" of the p55 tumor necrosis factor
(TNF) receptor and Fas/APO-1 prompts signaling for TNF and Fas/APO-1 effects. J. Biol. Chem. 270: 387-391.

16. Watanabe-Fukunaga $\mathrm{R}, \mathrm{Brannan} \mathrm{Cl}$, Itoh $\mathrm{N}$, et al. (1992) The cDNA structure, expression, and chromosomal assignment of the mouse Fas antigen. J. Immunol. 148: 12741279.

17. Suda T, Takahashi T, Golstein $P$, Nagata $S$. (1993) Molecular cloning and expression of the Fas ligand, a novel member of the tumor necrosis factor family. Cell 75: 1169-1178.

18. Kriegler M, Perez C, DeFay K, Albert I, Lu SD. (1988) A novel Form of TNF/Cachectin is a cell surface sytotoxic transmembrane protein: Ramifications for the complex physiology of TNF. Cell 53: 45-53.

19. Smith RA, Baglioni C. (1987) The active form of tumor necrosis factor is a trimer. $J$. Biol. Chem. 262: 6951-6954.

20. Tanaka $M$, Suda $T$, Takahashi T, Nagata $S$. (1995) Expression of the functional soluble form of human fas ligand in activated lymphocytes. $E M B O$ J. 14: 1129-1135.

21. Leist M, Gantner F, Bohlinger I, Germann PG, Tiegs G, Wendel A. (1994) Murine hepatocyte apoptosis induced in vitro and in vivo by TNF- $\alpha$ requires transcriptional arrest. J. Immunol. 153: 1778-1787.

22. Ogasawara J, Watanabe-Fukunaga $R$, Adashi M, et al. (1993) Lethal effect of the anti-Fas antibody in mice. Nature 364: 806808.

23. Tewari M, Dixit VM. (1995) Fas- and tumor necrosis factor-induced apoptosis is inhibited by the poxvirus crmA gene product. $J$. Biol. Chem. 270: 3255-3260.

24. Morimoto H, Yonehara S, Bonavida B. (1993) Overcoming tumor necrosis factor and drug resistance of human tumor cell lines by combination treatment with antiFas antibody and drugs or toxins. Cancer Res. 53: 2591-2596.

25. Hashimoto S, Ishii A, Yonehara S. (1991) The Elb oncogene of adenovirus confers cellular resistance to cytotoxicity of tumor necrosis factor and monoclonal anti-Fas antibody. Int. Immunol. 3: 343-351.

26. Kobayashi N, Hamamoto Y, Yamamoto N, Ishii A, Yonehara M, Yonehara S. (1990) Anti-Fas monoclonal antibody is cytocidal to human immunodeficiency virus-infected cells without augmenting viral replication. Proc. Natl. Acad. Sci. U.S.A. 87: 9620-9624.

27. Owen-Schaub LB, Meterissian S, Ford RJ. 
(1993) Fas/APO-1 expression and function on malignant cells of hematologic and nonhematologic origin. J. Immunother. 14: 234241.

28. Itoh N, Tsujimoto Y, Nagata S. (1993) Effect of bcl-2 on Fas antigen-mediated cell death. J. Immunol. 151: 621-627.

29. Clement M-V, Stamenkovitch I. (1994) Fas and tumor necrosis factor receptor-mediated cell death: Similarities and distinctions. $J$. Exp. Med. 180: 557-567.

30. Wong GHW, Goeddel DV. (1994) Fas antigen and p55 TNF receptor signal apoptosis through distinct pathways. J. Immunol. 152: 1751-1755.

31. Grell M, Krammer PH, Scheurich P. (1994) Segregation of APO-1/Fas antigen- and tumor necrosis factor receptor-mediated apoptosis. Eur. J. Immunol. 24: 2563-2566.

32. Schulze-Osthoff $\mathrm{K}$, Krammer PH, Dröge W. (1994) Divergent signalling via APO-1/fas and the TNF receptor, two homologous molecules involved in physiological cell death. EMBO J. 13: 4587-4596.

33. Lehmann V, Freudenberg MA, Galanos C. (1987) Lethal toxicity of lipopolysaccharide and tumor necrosis factor in normal and Dgalactosamine-treated mice. J. Exp. Med. 163: 657-663.

34. Tiegs G, Wolter M, Wendel A. (1989) Tumor necrosis factor is a terminal mediator in galactosamine/endotoxin hepatitis in mice. Biochem. Pharmacol. 38: 627-631.

35. Mizuhara H, O'Neill E, Seki N, et al. (1994) T cell activation-associated hepatic injury: $\mathrm{Me}$ diation by tumor necrosis factors and protection by interleukin 6. J. Exp. Med. 179: 15291537.

36. Gantner F, Leist M, Lohse AW, Germann PG, Tiegs G. (1995) Concanavalin A-induced Tcell-mediated hepatic injury in mice: The role of tumor necrosis factor. Hepatology 21: 190-198.

37. Chatenoud L, Ferran C, Bach JF. (1991) The anti-cd3-induced syndrome: A consequence of massive in vivo cell activation. Curr. Top. Microbiol. Immunol. 174: 121-132.

38. Miethke T, Wahl C, Heeg K, Echtenacher B, Krammer PH, Wagner H. (1992) T cell-mediated lethal shock triggered in mice by the superantigen staphylococcal enterotoxin B: Critical role of tumor necrosis factor. J. Exp. Med. 175: 91-98.

39. Miethke T, Duschek K, Wahl C, Heeg K, Wagner H. (1993) Pathogenesis of the toxic shock syndrome: $\mathrm{T}$ cell mediated lethal shock caused by the superantigen TSST-1. Eur. J. Immunol. 23: 1494-1500.

40. Nagaki M, Muto Y, Ohnishi H, et al. (1994) Hepatic injury and lethal shock in galactosamine-sensitized mice induced by the superantigen staphylococcal enterotoxin B. Gastroenterology 106: 450-458.

41. Leist $M$, Gantner $F$, Bohlinger I, Tiegs $G$, Germann PG, Wendel A. (1995) Tumor necrosis factor-induced hepatocyte apoptosis precedes liver failure in experimental murine shock models. Am. J. Pathol. 146: 12201234.

42. Gantner F, Leist M, Jilg S, German PG, Freudenberg MA, Tiegs G. (1995) Tumor necrosis factor-induced hepatic DNA fragmentation as an early marker of $\mathrm{T}$ cell-dependent liver injury in mice. Gastroenterology 109: 166-176.

43. Hiramatsu N, Hayashi N, Katayama K, et al. (1994) Immunohistochemical detection of fas antigen in liver tissue of patients with chronic hepatitis C. Hepatology 19: 13541359.

44. Galle PR, Hofmann WJ, Otto G, Stremmel W, Runkel L. (1995) Involvement of the APO-1/fas receptor and ligand in liver damage. Gastroenterology 108: Al068.

45. Rothe J, Lesslauer $\mathrm{W}$, Lötscher $\mathrm{H}$, et al. (1993) Mice lacking the tumour necrosis factor receptor 1 are resistant to TNF-mediated toxicity but highly susceptible to infection by listeria monocytogenes. Nature 364: 798800.

46. Espevik T, Nissen-Meyer J. (1986) A highly sensitive cell line, WEHI 164 clone 13, for measuring cytotoxic factor tumor necrosis factor from human monocytes. J. Immunol. Methods 95: 99-105.

47. Seglen PO. (1973) Preparation of rat liver cells: Enzymatic requirements for tissue dispersion. Exp. Cell. Res. 82: 391-398.

48. Bergmeyer HU. (1984) Methods of Enzymatic Analysis. 3rd Ed. Verlag Chemie, Weinheim, Vol. 82.

49. Mosmann T. (1983) Rapid colorimetric assay for cellular growth and survival: Application to proliferation and cytotoxicity assays. $J$. Immunol. Methods 6: 55-63.

50. Wyllie AH. (1980) Glucocorticoid-induced thymocyte apoptosis is associated with endogenous endonuclease activation. Nature 284: 555-556.

51. Mariani SM, Matiba B, Armandola EA, 
Krammer PH. (1994) The APO-1/Fas (CD95) receptor is expressed in homozygous MRL/ lpr mice. Eur. J. Immunol. 24: 3119-3123.

52. Pfeffer K, Matsuyama T, Kündig TM, et al. (1993) Mice deficient for the 55kd tumor necrosis factor receptor are resistant to endotoxic shock, yet succumb to I. monocytogenes infection. Cell 73: 457-467.

53. Beutler B, Grau GE. (1993) Tumor necrosis factor in the pathogenesis of infectious diseases. Crit. Care Med. 21: S423-S435.

54. Cerami A, Beutler B. (1988) The role of cachectin/TNF in endotoxic shock and cachexia. Immunol. Today 9: 28-30.

55. Westendorp MO, Frank R, Ochsenbauer C, et al. (1995) Sensitization of T cells to CD95mediated apoptosis by HIV-1 tat and gp 120 . Nature 375: 497-500.

56. Rouvier E, Luciani MF, Golstein P. (1993) Fas involvement in $\mathrm{Ca}^{2+}$ independent $\mathrm{T}$ cellmediated cytotoxicity. J. Exp. Med. 177: 195200.

57. Oberhammer F, Bursch W, Parzefall W, et al. (1991) Effect of transforming growth factor $\beta$ on cell death of cultured rat hepatocytes. Cancer Res. 51: 2478-2485.

58. Schwall RH, Robbins $\mathrm{K}$, Jardieu P, Chang L, Lai C, Terrell TG. (1993) Activin induces cell death in hepatocytes in vivo and in vitro. Hepatology 18: 347-356.

59. Nolan JP. (1989) Intestinal endotoxins as mediators of hepatic injury-An idea whose time has come again. Hepatology 10: 887891.

60. Laskin DL. (1990) Nonparenchymal cells and hepatotoxicity. Semin. Liver Dis. 10: 293304.

Contributed by E. Beutler on October 25, 1995.
61. Steininger R, Roth E, Függer R, et al. (1994) Transhepatic metabolism of TNF-alpha, IL-6, and endotoxin in the early hepatic reperfusion period after human liver transplantation. Transplantation 58: 179-182.

62. Adachi Y, Bradford BU, Gao W, Bojes HK, Thurman RG. (1994) Inactivation of Kupffer cells prevents early alcohol-induced liver injury. Hepatology 20: 453-460.

63. Gilles PN, Guerrette DL, Ulevitch RJ, Schreiber RD, Chisari FV. (1992) HBsAg retention sensitizes the hepatocyte to injury by physiological concentrations of interferon-gamma. Hepatology 16: 655-663.

64. Laskin DL, Gardner CR, Price VF, Jollow DJ. (1995) Modulation of macrophage functioning abrogates the acute hepatotoxicity of acetaminophen. Hepatology 21: 1045-1050.

65. Barriault C, Audet M, Yousef IM, Tuchweber B. (1995) Effect of agents which modify reticuloendothelial function on acute phalloidin-induced lethality and hepatotoxicity in mice. Toxicol. Appl. Pharmacol. 131: 206-215.

66. Czaja MJ, Xu J, Ju Y, Alt E, Schmiedeberg P. (1994) Lipopolysaccharide-neutralizing antibody reduces hepatocyte injury from acute hepatotoxin administration. Hepatology 19: 1282-1289.

67. Ishiyama H, Ogino K, Hobara T. (1995) Role of Kupffer cells in rat liver injury induced by diethyidithiocarbamate. Eur. J. Pharmacol. 292: 135-141.

68. Edwards MJ, Keller BJ, Kauffman, Thurman RG. (1993) The involvement of Kupffer cells in carbon tetrachloride toxicity. Toxicol. Appl. Pharmacol. 119: 275-279. 